\title{
Sequence analysis of plasmid pKJ50 from Bifidobacterium longum
}

\author{
Myeong S. Park, ${ }^{1}$ Dong W. Shin, ${ }^{1}$ Ke H. Lee ${ }^{1}$ and Geun E. Ji ${ }^{2}$ \\ Author for correspondence: Geun Eog Ji. Tel: +822880 8749. Fax: + 8228840305 . \\ e-mail : geji@mbio.snu.ac.kr
}

1 Department of Food Science and Technology, Seoul National University, Suwon, 441-744, Korea

2 Department of Food Science and Nutrition, Seoul National University, Seoul, 151-742, Korea

\begin{abstract}
The complete nucleotide sequence of a plasmid, pKJ50, isolated from an intestinal bacterium, Bifidobacterium longum $\mathrm{KJ}$, has been determined. The plasmid was analysed and found to be 4960 bp in size with a G+C content of $61.7 \mathrm{~mol} \%$. Computer analysis of sequence data revealed three major ORFs encoding putative proteins of 31.5 (ORFI), 24.5 (ORFII) and $38.6 \mathrm{kDa}$ (ORFIII). ORFI encodes a protein with a pl of 10.18 and shows relatively high amino acid sequence similarity (more than $60 \%$ ) with several plasmid replication proteins from Gram-positive and -negative bacteria. Southern blot analysis showed that pKJ50 accumulates an SsDNA intermediate, suggesting that it replicates by a rolling-circle mechanism. Upstream of ORFI, three sets of repeated sequences resembling iteron structures of related plasmids were identified. ORFIII encodes a protein with a pl of 10.97. It also shows a high level of amino acid sequence similarity with some plasmid mobilization proteins. Upstream of ORFIII, a 12 bp stretch resembles an oriT DNA sequence with inverted repeats identical to those found in conjugative plasmids. Hydropathy plot analysis of ORFII, encoding an acidic protein $(\mathrm{pl}=4.95)$, suggests it is a transmembrane protein. Several interesting palindromic sequences, repeat sequences and hairpin-loop structures around ORFI, which might confer regulatory effects on the replication of the plasmid, were also noted. Reverse transcriptase PCR (RTPCR) and in vitro translation confirmed the expression of ORFI and ORFII. RTPCR produced amplified DNA fragments of the expected sizes, corresponding to ORFI and ORFII. However, no RT-PCR product corresponding to ORFIII was obtained. In vitro translation showed protein bands of the expected sizes, corresponding to each ORF. A shuttle vector capable of transforming Bifidobacterium animalis MB209 was constructed by cloning pKJ50 and a chloramphenicol resistance gene into pBR322.
\end{abstract}

Keywords: Bifidobacterium longum, plasmid, gene expression, shuttle vector, replication

\section{INTRODUCTION}

Bifidobacteria were first discovered in 1899 by Tissier at the Institut Pasteur, Paris. They are considered to play an important role in the proper balance of normal intestinal flora and exert many beneficial effects on the health of human beings. This may arise as a consequence of altered intestinal $\mathrm{pH}$, specifically through the release of acetic and lactic acids. Also, the contribution of

\footnotetext{
Abbreviation: RT-PCR, reverse transcriptase PCR.
}

The GenBank accession number for the sequence reported in this paper is U76614. bifidobacteria to the reinforcement of host immune functions and improved resistance to cancer have been reported (Lee et al., 1993). As a consequence, biotechnological development of bifidobacteria probiotic strains with improved characteristics is becoming popular. To develop a cloning vector for modification of bifidobacteria, a comprehensive understanding of the replication mechanism and characterization of bifidobacteria plasmids is necessary. However, problems may arise as a consequence of the difficulties of isolation and cultivation of bifidobacteria. Only a few studies have been published concerning the isolation and characterization of plasmids from bifidobacteria (Bourget et al., 1993; Matteuzzi et al., 1990; Sgorbati et al., 1986) 
and vector construction using Bifidobacterium plasmids (Argnani et al., 1996; Missich et al., 1994). Recently, the sequence of the 1847 bp plasmid from Bifidobacterium longum B2577, whose ORF showed amino acid sequence homology with peptides from pXZ10142 of Corynebacterium glutamicum and pAL5000 of Mycobacterium fortuitum, was reported (Rossi et al., 1996).

In this study, we report the full sequence of $\mathrm{pKJ} 50$, one of the two plasmids that exist in B. longum KJ (Park et al., 1997). The analysis of gene structure revealed that the replication protein (Rep; ORFI) and mobilization protein (Mob; ORFIII) of pKJ50 are highly homologous with those of various Gram-positive and -negative bacteria. However, the Rep protein of pKJ50 shows little homology with that of pMB1 from $B$. longum B2577. Moreover, putative Mob and membrane proteins have been identified and structurally analysed. The replication mechanism of pKJ50 was investigated by $\mathrm{S1}$ nuclease treatment and Southern hybridization. Reverse transcriptase PCR (RT-PCR) and in vitro translation experiments confirmed the expression of each ORF. In addition, a shuttle vector capable of transforming Escherichia coli and Bifidobacterium animalis MB209 was constructed.

\section{METHODS}

Bacterial strains, media and plasmids. E. coli DH5 $\alpha$, cultured at $37^{\circ} \mathrm{C}$ in Luria broth with vigorous shaking, was used for transformation. Ampicillin was used at a concentration of $50 \mu \mathrm{g} \mathrm{ml}^{-1}$. Bifidobacteria were cultured in MRS broth (Difco) supplemented with $0.05 \%$ (final concentration) cysteine $/ \mathrm{HCl}$ at $37^{\circ} \mathrm{C}$. Multicopy plasmid vector pUC19 was used for cloning pKJ50. B. animalis MB209 (kindly provided by $\mathrm{Dr}$ Diego Matteuzzi, Italy) was used as the transformation host for the constructed shuttle vector.

General cloning techniques and sequence analysis. Smalland large-scale plasmid DNA preparation from E. coli. restriction enzyme digestion, ligation and transformation of $E$. coli was carried out according to the procedures of Sambrook et al. (1989). Plasmid DNA from Bifidobacterium strains was prepared as described by Park et al. (1997). DNA was recovered from agarose gels by using the GeneClean Kit (Bio101). For the sequencing reaction, plasmid DNA was prepared from $E$. coli DH5 $\alpha$ with the Wizard Minipreps DNA Purification System (Promega), according to the manufacturer's instructions. Unidirectional deletion mutants were constructed with the Kilo-Sequencing Deletion Kit (Takara Shuzo). Sequencing reactions were performed using the Cy5 AutoRead Sequencing Kit (Pharmacia) and ALF DNA Sequencer (Pharmacia). DNA and amino acid sequence data analyses were performed using the DNASIS and PROSIS programs (Hitachi Software Engineering), respectively. DNA and amino acid sequence homology searches were done online using the BLAST server maintained at the National Center for Biotechnology Information, Bethesda, MD, USA (http://www.ncbi.nlm.nih.gov/recipon/blast-search.html) and the programs BLASTN, BLASTP, BLASTX and TBLASTN (Altschul et al., 1990). Multiple sequence alignments of related amino acid sequences were performed using CLUSTAL V (Higgins, 1994). Hydropathy plot analysis of each deduced amino acid was done using an Internet program (http://www.microbiology.adelaide.edu.au/leam/index.htm).
Southern blot analysis and detection of ssDNA. Southern blot analysis was performed using a digoxigenin (DIG) DNA Labelling and Detection Kit (Boehringer Mannheim), according to manufacturer's protocol. ssDNA was detected by the method of Leenhouts et al. (1991), which relies on comparing plasmid DNA before and after selective digestion of ssDNA with $\mathrm{S} 1$ endonuclease.

Total RNA isolation from B. longum KJ and RT-PCR. Total RNA was isolated using the High Pure RNA Isolation Kit (Boehringer Mannheim). B. longum KJ was cultivated to midexponential phase $\left(\mathrm{OD}_{600}=0 \cdot 5\right)$. From this culture, about $1 \times 10^{9}-1 \times 10^{10}$ c.f.u. $\mathrm{ml}^{-1}$ were harvested by centrifugation at $2000 \mathrm{~g}$ for $5 \mathrm{~min}$ and the pellet was resuspended in $200 \mu \mathrm{l}$ $10 \mathrm{mM}$ Tris/HCI (pH 8.0) supplemented with $4 \mu \mathrm{l}$ lysozyme solution $\left(50 \mathrm{mg} \mathrm{ml}^{-1}\right)$ and incubated for $10 \mathrm{~min}$ at $37^{\circ} \mathrm{C}$. Four hundred microlitres of lysis/binding buffer ( $4.5 \mathrm{M}$ guanidine/ $\mathrm{HCl}, 50 \mathrm{mM}$ Tris $/ \mathrm{HCI}, 30 \%$ Triton X-100, $\mathrm{pH} 6.6$ ) was added to the solution, mixed well and transferred to the upper reservoir of a High Pure filter tube. After centrifugation at $8000 \mathrm{~g}$ for $15 \mathrm{~s}$ to discard the flow-through, $100 \mu \mathrm{l} \mathrm{DNase} \mathrm{I}$ solution was added to the tube and incubated for $60 \mathrm{~min}$ at room temperature. It was washed twice with wash buffer I (5 $\mathrm{M}$ guanidine/ $\mathrm{HCl}, 20 \mathrm{mM}$ Tris/ $\mathrm{HCI}, \mathrm{pH} \mathrm{6.6)} \mathrm{and} \mathrm{buffer} \mathrm{II}$ ( $20 \mathrm{mM} \mathrm{NaCl}, 2 \mathrm{mM}$ Tris/HCI, pH 7.5) by centrifugation at $8000 \mathrm{~g}$ for $15 \mathrm{~s}$. Then the filter tube was transferred to a sterile microcentrifuge tube and the RNA was eluted with $50 \mu \mathrm{l}$ elution buffer (nuclease-free, sterile double-distilled water) by centrifugation at $8000 \mathrm{~g}$ for $1 \mathrm{~min}$. The RNA solution was aliquoted and stored at $-70^{\circ} \mathrm{C}$. RT-PCR was performed using the Access RT-PCR system (Promega), according to the manufacturer's protocol. The synthesis of the first cDNA strand was carried out using specific primers [for ORFI, MS005 (5' CAGTCATGACCGATGAGATC 3') and MS006 (5' GAGTATCAGGGTCGAGCGCC 3'); for ORFII; MSO01 ( $5^{\prime}$ CGGGCATGCATGACTTTTCG $3^{\prime}$ ) and MS002 $\left(5^{\prime}\right.$ ATCCTTACCAGCGGGTAACG $\left.3^{\prime}\right)$; for ORFIII; MSO03 $\left(5^{\prime}\right.$ TCAAGCCGTGTCTTGAACCT $\left.3^{\prime}\right)$ and MSO04 (5' CGCGTCGAGCATGTATGCAC $3^{\prime}$ )] and AMV reverse transcriptase (Promega) at $48{ }^{\circ} \mathrm{C}$ for $45 \mathrm{~min}$. PCR was performed by using the same primers and Taq DNA polymerase (Promega) for 40 cycles as follows: denaturation at $94^{\circ} \mathrm{C}$ for $30 \mathrm{~s}$, annealing at $60^{\circ} \mathrm{C}$ for $1 \mathrm{~min}$ and elongation at $68^{\circ} \mathrm{C}$ for $2 \mathrm{~min}$. This was followed by one final extension step at $68^{\circ} \mathrm{C}$ for $7 \mathrm{~min}$.

Coupled in vitro transcription/translation. In vitro translation was performed using the E. coli T7 S30 extract system for circular DNA (Promega), according to the manufacturer's protocol. Four micrograms of template DNA, $5 \mu \mathrm{l}$ amino acid mixture without methionine, $20 \mu \mathrm{l} \mathrm{S30}$ premix without amino acids, $1 \mu{ }^{35}$ S-methionine $\left(4.55 \times 10^{13} \mathrm{~Bq} \mathrm{ml}^{-1}\right)$ and $15 \mu \mathrm{l} \mathrm{T} 7$ S30 extract were mixed gently, sterilized double-distilled water was added to $50 \mu \mathrm{l}$ and the mixture was incubated at $37^{\circ} \mathrm{C}$ for $2 \mathrm{~h}$. The reaction was stopped by placing the tube on ice for $5 \mathrm{~min}$. Five microlitres of reaction mixture was transferred to a new microcentrifuge tube and $20 \mu \mathrm{l}$ acetone was added and mixed. After $15 \mathrm{~min}$ incubation on ice, the mixture was centrifuged at $12000 \mathrm{~g}$ and the supernatant was discarded and dried for $15 \mathrm{~min}$. The pellet was resuspended in $20 \mu \mathrm{l}$ SDS sample buffer and boiled at $100^{\circ} \mathrm{C}$ for $3 \mathrm{~min}$. It was analysed by conventional SDS-PAGE (15\% acrylamide) and visualized by autoradiography.

Detection of ssDNA replication intermediate. To detect the replication intermediate, Southern blot analysis was performed according to the method of Leenhouts et al. (1991). 

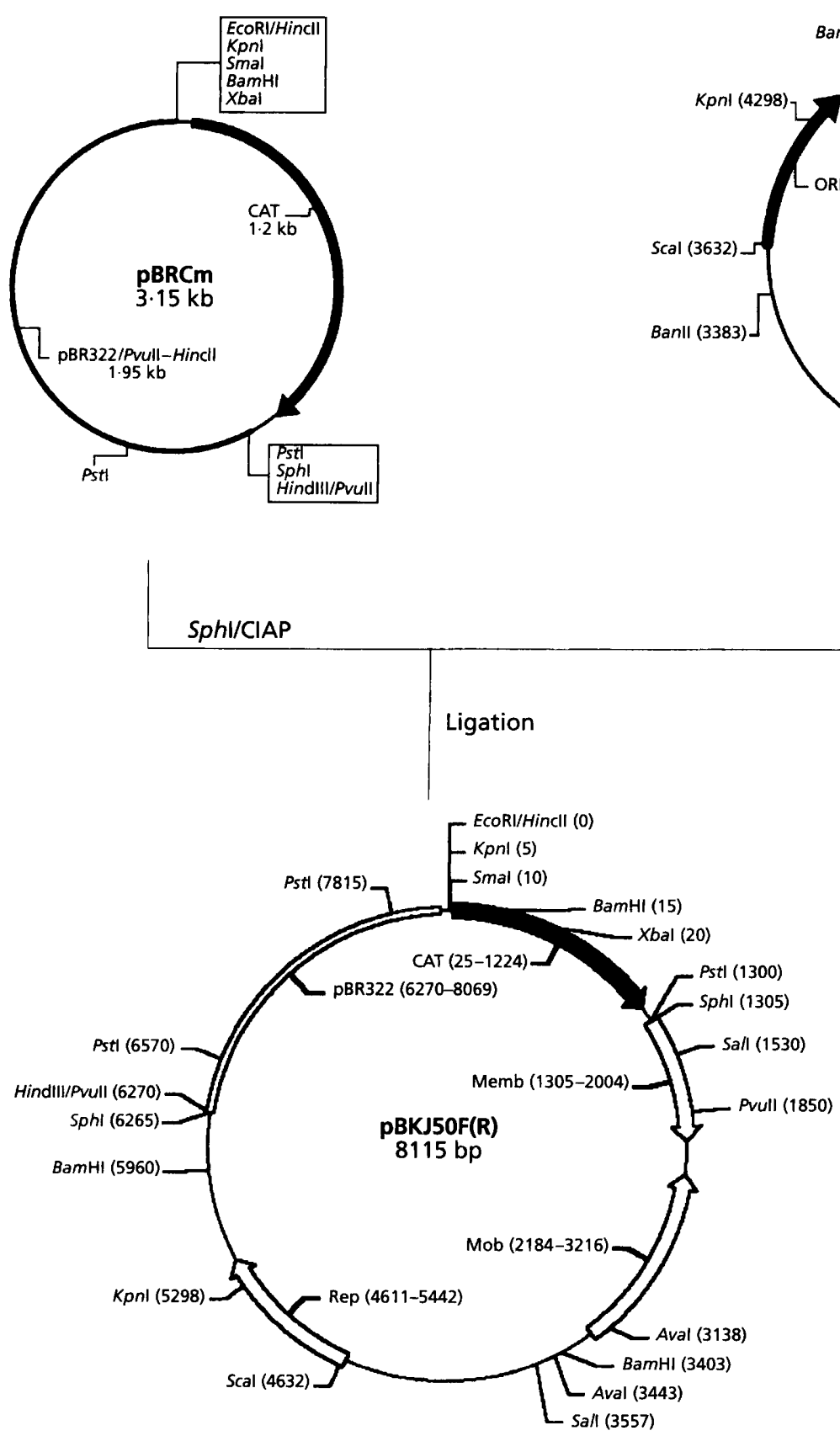

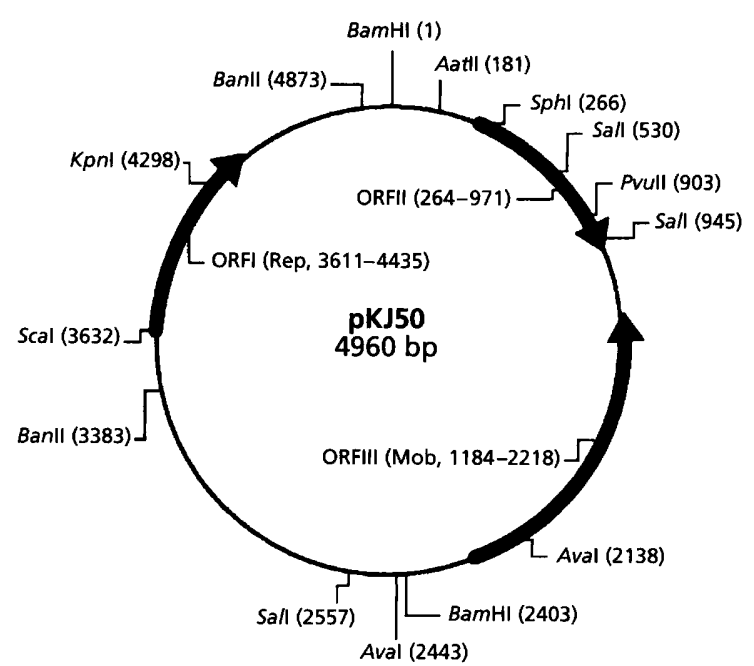

Sphl
Fig. 1. Restriction enzyme map of plasmid pKJ50 and construction of the $E$. coli-B. animalis shuttle vectors pBKJ50F and pBKJ50R. pBRCm was constructed by ligating a $1.3 \mathrm{~kb}$ EcoRI-HindIII fragment (cat gene), blunt-ended using T4 DNA polymerase, with a $1.8 \mathrm{~kb}$ Pvul-Hincll fragment of pBR322. pBKJ50F (forward) and PBKJ50R (reverse) differ only in the direction in which pKJ50 is inserted. Site coordinates are given in bp in parentheses. ORFs and their putative proteins are shown: CAT, chloramphenicol acetyltransferase; CIAP, calf intestinal alkaline phosphatase; Rep, replication protein; Memb, membrane protein; Mob, mobilization protein.
MB209. For the construction of the shuttle vector, the $1.3 \mathrm{~kb}$ staphylococcal chloramphenicol acetyltransferase gene (cat) (EcoRI-HindIII fragment of pEK104; Park et al., 1989) was first ligated with the $1.8 \mathrm{~kb}$ pBR322 PvulI-HincII fragment and designated pBRCm (Fig. 1). The cat gene enabled $E$. coli transformants carrying pBRCm to grow in the presence of $25 \mu \mathrm{g}$ chloramphenicol $\mathrm{ml}^{-1}$. Then, E. coli-B. animalis shuttle vectors $\mathrm{pBKJ} 50 \mathrm{~F}$ and $\mathrm{pBKJ} 50 \mathrm{R}$ were constructed by cloning the whole pKJ50 plasmid into the $S p h I$ site of $\mathrm{pBRCm}$ as shown in Fig. 1. Electrocompetent cells of B. animalis MB209 were prepared according to the method of Argnani et al. (1996). The pulse generator of Easy Ject One (EquiBio) was set at $10 \mathrm{kV} \mathrm{cm}^{-1}, 200 \Omega$ and $40 \mu \mathrm{F}$.

\section{RESULTS AND DISCUSSION DNA sequence of pKJ50}

Plasmid pKJ50 was originally isolated from B. longum KJ screened from the faeces of an infant by Park et al. (1997). After its initial isolation, B. longum KJ was subcultured more than 100 times under non-selective conditions without losing its plasmid, indicating that replication of pKJ50 in this strain is extraordinarily stable under laboratory conditions. For the structural analysis of pKJ50 in this study, it was subcloned and fully sequenced as follows. pKJ50 was linearized with 


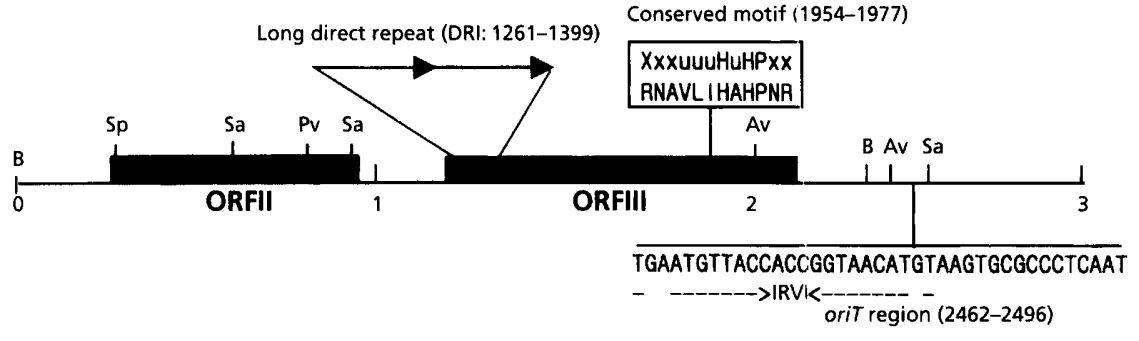

Iteron sequence (3452-3569)

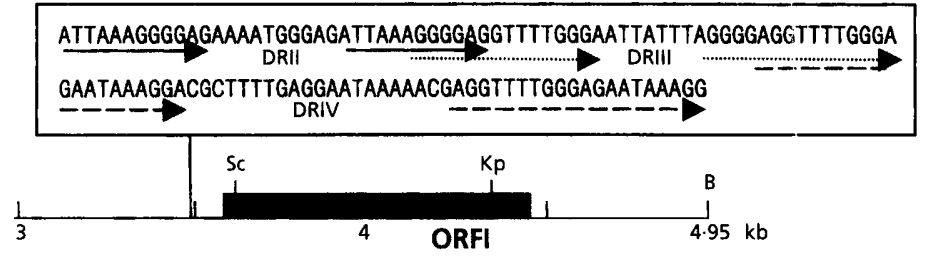

Fig. 2. Schematic representation of the nucleotide sequence of pKJ50. Each ORF is indicated by a black box. ORFI and ORFII read from left to right and ORFIII reads from right to left. The nucleotide sequences of the putative DNA iteron region (3452-3569) and the oriT region (2462-2496) are shown. The amino acid sequence of the highly conserved motif (1954-1977) in ORFIII is indicated in a box $(u$, hydrophobic residue; $x$, non-consensus residue). Abbreviations: Av, Aval; B, BamHI; Kp, Kpnl; Pv, Pvull; Sa, Sall; Sc, Scal; Sp, Sphl.
$K p n I$ and cloned into the $K p n I$ site of pUC19 to construct pMS50. The BamHI fragments of pMS50 were subcloned into the pUC19 BamHI site to produce $\mathrm{p} 3400$ (self-ligation of the $3.4 \mathrm{~kb} \mathrm{BamHI}$ fragment), p51 and p51R (containing the $2.4 \mathrm{~kb} \mathrm{BamHI}$ fragment in both forward and reverse directions), and p46 and p46R (containing the $1.9 \mathrm{~kb} \mathrm{BamHI}$ fragment in both directions). Deletion mutants were prepared and sequenced on both strands. A diagrammatic representation of the nucleotide sequence of pKJ50 is shown in Fig. 2 [numbering starts at Bam HI site 1 (Fig. 1)]. The $\mathrm{G}+\mathrm{C}$ content is $61.7 \mathrm{~mol} \%$, slightly higher than that of the genome $(60.1 \mathrm{~mol} \%$; Bezkorovainy \& MillerCatchpole, 1989) of Bifidobacterium sp. There are three putative ORFs encoding basic (ORFI, pI $=10 \cdot 18$, $31.5 \mathrm{kDa}$ ), acidic (ORFII, $\mathrm{pI}=4.95,24.5 \mathrm{kDa}$ ) and basic (ORFIII, $\mathrm{pI}=10 \cdot 97,38.6 \mathrm{kDa}$ ) proteins. These ORFs are indicated in the restriction map of pKJ50 (Fig. 1).

\section{Replication by a rolling-circle mechanism}

There is no report of the replication mechanisms of bifidobacteria plasmids to our knowledge. To examine if Bifidobacterium plasmids replicate via the rollingcircle mechanism, accumulation of ssDNA intermediates in plasmid-harbouring cells was examined. Plasmid DNA was isolated from B. longum $\mathrm{KJ}$ and divided into two portions, one of which was treated with endonuclease S1 to digest ssDNA. Southern blot analysis of the S1-digested and non-digested plasmid DNA fractions, using pKJ50 linearized with $K p n I$ as probe, revealed that the ssDNA intermediate disappeared after treatment with endonuclease S1 (Fig. 3). This suggests that pKJ50 produces ssDNA as a replication intermediate. Numerous plasmids of Grampositive bacteria have been reported to replicate via single-stranded intermediates, probably by rolling-circle replication similar to the ssDNA phages of E. coli (Gruss \& Ehrlich, 1989).

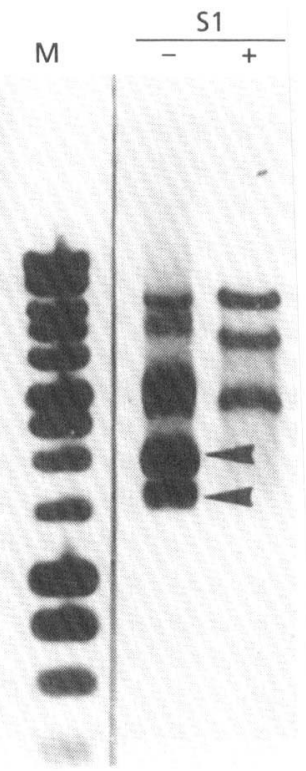

Fig. 3. Detection of the SsDNA replication intermediate of pKJ50. ssDNAs are indicated by arrows. Plasmid DNAs were isolated from $B$. longum $\mathrm{KJ}$ and divided into two portions, one of which was treated with endonuclease $\$ 1$ to digest ssDNA (lane + ). Southern blot analysis using pKJ50 linearized with $K p n l$ revealed that the ssDNA intermediate disappeared after treatment with endonuclease $\mathrm{S} 1$. Lane $\mathrm{M}$, molecular mass markers.

\section{Replication protein coding region}

The deduced amino acid sequence of the pKJ50 Rep protein resembles that of the Rep proteins of pEFC1 from Enterococcus faecalis ( $45 \%$ identity, $68 \%$ similarity; GenBank D85392), RepA of pLA103 from Lactobacillus acidophilus (43\% identity, $64 \%$ similarity; Kanatani et al., 1995), RepB of Campylobacter coli (46\% identity, $63 \%$ similarity; GenBank S49368), RepA of Pediococcus halophilus ( $54 \%$ identity, $64 \%$ simi- 
larity; GenBank S38639), the $54.52 \mathrm{kDa}$ protein of pHPM 180 from Helicobacter pylori (50\% identity, $66 \%$ similarity; GenBank U12689) and the putative RepA of pHeI1 from $H$. pylori (48\% identity, $64 \%$ similarity; Heuermann \& Haas, 1995). Multiple amino acid sequence alignment analysis showed highly conserved regions between these sequences (data not shown). Regions upstream of ORFI contain an AT-rich sequence followed by three sets of direct repeat sequences flanking each other (DRII, DRIII and DRIV, Fig. 2). This motif resembles the so-called DNA iteron structure, a feature typical of the ori site of many bacterial plasmids. These motifs act as binding sites for the Rep protein and may control plasmid copy number and incompatibility (Frey et al., 1992). All of the identified replicons of theta-type plasmids, such as the pCI305/pWV02 family of Lactococcus, contain the tandem repeat sequences found in the repA locus of pCI305; however, the sequences of the repeats are variable (Frere et al., 1993; Kiewiet et al., 1993; Seegers et al., 1994). No conserved regions encoded by replication proteins involved in the rollingcircle mechanism (Wang \& Macrina, 1995) were observed in pKJ50. Comparison of the pKJ50 Rep protein amino acid sequence with that of plasmid pMB1 from B. longum B2577 (Rossi et al., 1996) and pAP1 from B. asteroides (GenBank Y11549) showed no significant homology.

\section{Mobilization protein coding region}

ORFIII, encoding a putative $38.6 \mathrm{kDa}$ protein with a $\mathrm{pI}$ of $10 \cdot 97$, showed significant amino acid sequence homology with some mobilization proteins, e.g. MobA of $E$. coli plasmid RSF1010 (55\% identity, 69\% similarity; Drolet et al., 1990; Frey et al., 1992) and the $43 \mathrm{kDa}$ relaxation protein from pSC101 $(55 \%$ identity, $70 \%$ similarity; Drolet et al., 1990) of Salmonella typhimurium. It also shared amino acid sequence homology with the nicking enzyme of pGO1 from Staphylococcus aureus (35\% identity, $60 \%$ similarity; Climo et al., 1996) and TraA of pTiC58 from Agrobacterium tumefaciens $(37 \%$ identity, $68 \%$ similarity ; Cook \& Farrand, 1992). The sequence alignment of these proteins also showed highly conserved domains (Fig. 4). One of those motifs (boxed region in Fig. 4) is identical to that previously reported by Tatyana \& Eugene (1992) as the most prominent among three consensus sequences of the mobilization proteins of the pUB110 family, the pMV158 family and the phage family. Another interesting aspect was the presence of a putative oriT site in pKJ50 with an identical 12 bp sequence found in Gramnegative plasmids RSF1010, pTF1, pSC101 and R1162 as well as the published oriT sequence of streptococcal plasmid pIP501 (Wang \& Macrina, 1995), staphylococcal plasmid pGO1 (Climo et al., 1996) and $A$. tumefaciens plasmid pTiC58 (Cook \& Farrand, 1992). The inverted repeat sequence which is commonly found in the upstream region of the oriT sequence was also present in pKJ50 (IRVI). These results suggest the possibility of gene transfer mechanisms via bacterial conjugation in the genus Bifidobacterium. However, no
pKJ50 M------RDERTGEAFNGFGR-RSASSMYARCCPRA--------RPA

pIP501 MTI------AKRENGKRSLIAMASYRSGEKLYSELYEKTNLYNHRTVKPE

RSF 1010 MAIYHLTAKTGSRSGGQSARAKADY IQREGKYARDMDEVL-HAESGHMPE

pSC101 MASYHLSVKTGGKG---SASPHADY IAREGKYAREKDSDLEHKESGNMPA

$$
\text { * . . . * * * }
$$

pKJ50 STSTRSVCST------PSRWPR-NVPTRGPR----RRSWSPCPASSTPAN pIP501 AFILKPDYVPNEFLDRQTLWNKMELAEKSPNAQLCREVNVALPIELNNSD

RSF1010 FV-ERP----ADY-----WDAADLYERA-NGRLFKEVEFALPVELTLDQ

pSC101 WAAHKP----SEF-----WKAADTSERA-NGCTYREIEIALPRELKPEQ

pKJ50 AFRALEDF ISWNITANGYACTYAIHTDK----DGRNPHAHILVANR---R PIP501 QRMLIEDFVKDNFVNEGMIADVAIHRD-----DENNPHAHIMLTMR---E

RSF 1010 QKALASEFAQHLTGAERLPYTLAIHA-----GGGENPHCHLMISERINDG

pSC101 RLELVRDFVQQEIG-DRHAYQFAIHNPKAAIAGGEQPHAHIMFSERINDG

pKJ50 IDPKTGRWAAKSRSEFALDANGRRI---------PVIDPDTGRQKIGARNRKVW pIP501 VDSE-GNILNKSHR IPKLDENGNQIFNEKGQRVTVSIKTNDWGRKSLVSE IRKDW RSF 1010 IERPAAQWFKRYNGKTP--------EKGGAQKTEALKPKA-----WLEQTREAW pSC101 IHRDPEQYFKRANTKEP------DAVAQKRHVSGKHRPNAKNTLLPRGRR-W

Fig. 4. Alignment of various Mob proteins. The aligned motifs are extracted from complete alignments generated by program CLUSTAL $V$ as described. Amino acid residues conserved in all the aligned sequences are marked as *. The highly conserved motif is indicated in bold type ( $u$, hydrophobic residue, $x$, nonconsensus residue). Data from: this study, pKJ50; Wang \& Macrina (1995), plP501; Frey et al. (1992), RSF1010; Drolet et al. (1990), pSC101.

evidence supporting this has been reported to our knowledge.

\section{ORFII coding region}

Hydropathy plot analysis suggests that ORFII is a transmembrane protein with two transmembrane amino acid segments (78-98 and 197-216). The first segment is located within a helical structure $(65-110)$ as shown by the PROSIS program. In general, segments containing about 20-30 aa with a high degree of hydrophobicity are considered to be long enough to span a membrane as an $\alpha$-helix (Eisenberg, 1984). The amino acid sequence homology search of the 171-214 segment showed $38 \%$ identity with transferrin-binding protein 2 of Haemophilus influenzae (Loosmore et al., 1996) and the 159-204 segment showed 34\% identity with the multidrug resistance protein of Candida albicans (Prasad et al., 1995). This suggests that ORFII may be a receptor membrane protein; however, its exact function requires elucidation.

\section{Secondary structure}

There are six direct repeats, eight inverted repeats and four stem-loop structures in the pKJ50 plasmid DNA sequence. DRI is $68 \mathrm{bp}$ long and is followed directly by stem-loop III (SLIII). This sequence may play an important role in the control of plasmid replication by providing a target site for translation and transcription factors. DRV and DR VI display an interesting structure 


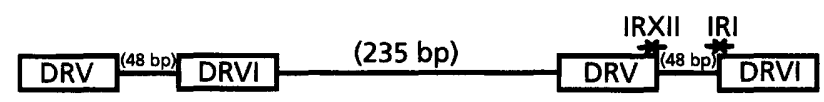

Fig. 5. Direct repeats with identical spacer length. DRV (4589-4612, 4915-4938) and DRVI (27-45, 4661-4679) display an interesting structure with spacers of identical length (48 bp) but different nucleotide sequence between each DRVIDRVI pair.

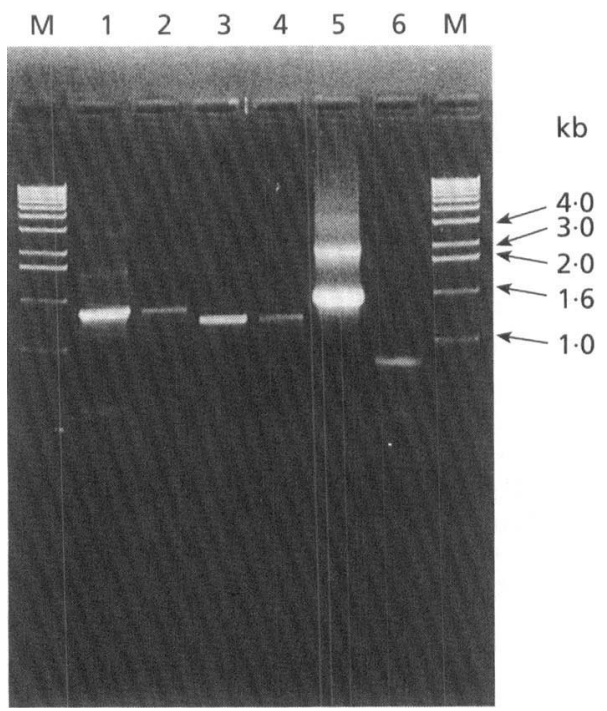

Fig. 6. Confirmation of expression of each ORF of pKJ50 by RTPCR and PCR. Lanes: 1, PCR product with pKJ50 plasmid DNA template and primers MS005 and MS006; 2, RT-PCR product with total RNA from B. longum KJ and primers MSO05 and MS006; 3, PCR product with pKJ50 plasmid DNA template and primers MSO01 and MSO02; 4, RT-PCR product with total RNA from B. longum KJ and primers MSO01 and MS002; 5, PCR product with pKJ50 plasmid DNA template and primers MSO03 and MS004; 6 , RT-PCR product with total RNA from $B$. longum $\mathrm{KJ}$ and primers MSO03 and MSO04; M, molecular mass markers.

(Fig. 5) with identical spacers ( $48 \mathrm{bp}$ ) between the leftand right-hand DRV/DRVI pairs. Moreover, the righthand DRV/DRVI pair is flanked with inverted repeats which may differentiate the two sets of direct repeats. However, the significance of these structures remains to be elucidated.

\section{Confirmation of expression of ORFI and ORFII}

Sequence analysis of pKJ50 suggests that this plasmid has three ORFs as described above. This was confirmed by RT-PCR and a coupled in vitro transcription/ translation reaction using several DNA templates containing pKJ50 fragments and ${ }^{35} \mathrm{~S}$-methionine as chase material. RT-PCR was used to detect the expected mRNA that might be transcribed from each ORF. By using three primer sets specific for the upstream and downstream sequences of each ORF, PCR products of the expected size could be detected for ORFI and ORFII (Fig. 6). The size of each RT-PCR product was identical to that of the PCR product produced by using the same

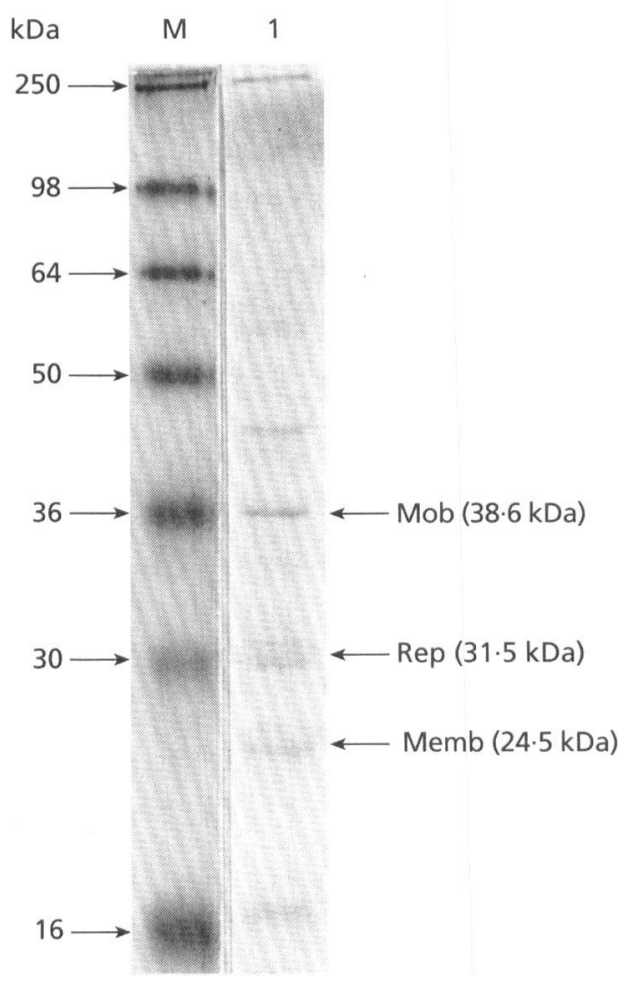

Fig. 7. Coupled in vitro transcription/translation of each ORF on pKJ50 (lane 1). Plasmid pKJ50 was expressed in the $E$. coli T7 S30 Extract System (Promega). The proteins were expressed as described in Methods using ${ }^{35} \mathrm{~S}$-methionine as chaser, resolved by SDS-PAGE ( $15 \%$ acrylamide) and visualized by autoradiography. Mob, putative mobilization protein; Rep, putative replication protein; Memb, putative membrane protein. Lane $M$, molecular mass markers.

primer sets and pKJ50 plasmid DNA. However, ORFIII, encoding the putative Mob protein, showed no RT-PCR product, although the PCR reaction with pKJ50 template produced a product of the expected size. This might suggest that ORFIII of pKJ50 is not usually expressed. When pKJ50 was used as template DNA, an in vitro translation reaction produced three major protein bands positioned at 31,24 and $38 \mathrm{kDa}$, corresponding to each ORF (Fig. 7).

\section{Shuttle vector construction}

E. coli-B. animalis shuttle vectors $\mathrm{pBKJ} 50 \mathrm{~F}$ and $\mathrm{pBKJ} 50 \mathrm{R}$ were constructed as described in Methods and Fig. 1. They were designed not to disturb the putative Rep protein. They were transformed into $B$. animalis MB209 with an efficiency of $2.0 \times 10^{2}$ c.f.u. $(\mu \mathrm{g} \text { DNA) })^{-1}$ by electroporation at $10 \mathrm{kV} \mathrm{cm}{ }^{-1}, 200 \Omega$ and $40 \mu \mathrm{F}$, and selected using $3 \mu \mathrm{g}$ chloramphenicol $\mathrm{ml}^{-1}$. The integrity of $\mathrm{pBKJ} 50 \mathrm{~F}$ was confirmed by PCR using the same sets of primers as above and comparing Southern hybridization patterns of plasmid DNA extracted from $B$. animalis transformants with those of pBKJ50. pBKJ50 and the plasmid isolated from the transformants showed the same PCR products and Southern hybridization 


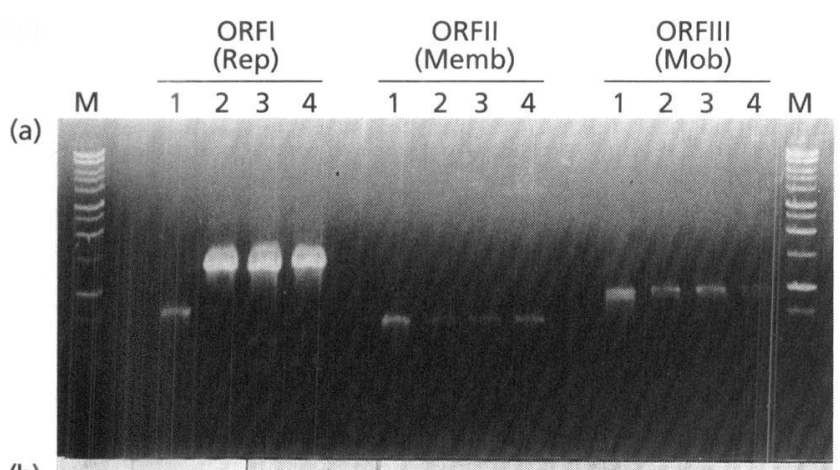

(b)

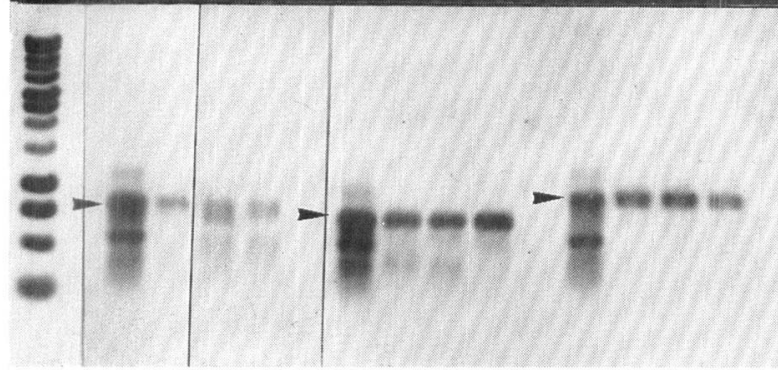

Fig. 8. Confirmation of transformation of $B$. animalis MB209 with pBKJ50 by PCR and Southern hybridization. The same sets of primers were used as described in the legend to Fig. 6. (a) PCR products amplified from each ORF separated by electrophoresis. (b) PCR products were hybridized with pKJ50 as probe and the specific products of each ORF are indicated with arrows. Lanes 1 and lanes 2-4 show PCR products and Southern hybridization patterns, respectively, of $\mathrm{pBKJ} 50$ and plasmids extracted from B. animalis MB209 transformants.

patterns, revealing that the plasmid was successfully transformed (Fig. 8a, b).

This study has shown that Rep and Mob proteins of the strictly anaerobic bacterium $B$. longum $\mathrm{KJ}$ are highly homologous with those of diverse and phylogenetically distant micro-organisms, and the expression of the putative Rep and membrane proteins has been investigated. It is possible that the rolling-circle mechanism of plasmid replication and mobilization is employed by $B$. longum $\mathrm{KJ}$. However, the presence of a different Rep protein in pMB1 of B. longum B2577 and pAP1 of $B$. asteroides suggests that at least two different modes of plasmid replication are possible in various Bifidobacterium strains. In addition, an E. coli-B. animalis shuttle vector was constructed and successfully transformed into B. animalis MB209. This shuttle vector should be a good candidate for the construction of improved cloning vectors, such as food-grade cloning and expression vectors, which can be used in Bifidobacterium species.

\section{ACKNOWLEDGEMENTS}

Part of this research was supported by the Korea Research Foundation. B. animalis MB209 was kindly provided by Dr Diego Matteuzzi, Italy. Plasmid pEK104 was obtained from Professor Hyo-lhl Chang at Korea University.

\section{REFERENCES}

Altschul, S. F., Gish, W., Miller, W., Myers, E. W. \& Lipman, D. J. (1990). Basic local alignment search tool. J Mol Biol 215, 403-410.

Argnani, A., Leer, R. J., van Luijk, N. \& Pouwels, P. H. (1996). A convenient and reproducible method to genetically transform bacteria of the genus Bifidobacterium. Microbiology 142, 109-114.

Bezkorovainy, A. \& Miller-Catchpole, R. (1989). Biochemistry and Physiology of Bifidobacteria. Boca Raton, FL: CRC Press.

Bourget, N., Simonet, J. M. \& Decaris, B. (1993). Analysis of the genome of five Bifidobacterium breve strains: plasmid content, pulsed-field gel electrophoresis genome size estimation and $r r n$ loci number. FEMS Microbiol Lett 110, 11-20.

Climo, M. W., Sharma, V. K. \& Archer, G. L. (1996). Identification and characterization of the origin of conjugative transfer (oriT) and a gene (nes) encoding a single-stranded endonuclease on the staphylococcal plasmid pGO1. J Bacteriol 178, 4975-4983.

Cook, D. M. \& Farrand, S. K. (1992). The oriT region of the Agrobacterium tumefaciens $\mathrm{Ti}$ plasmid pTiC58 shares DNA sequence identity with the transfer origins of RSF1010 and RK2/RP4 and with T-region borders. J Bacteriol 174, 6238-6246.

Drolet, M., Zanga, P. \& Lau, P. C. (1990). The mobilization and origin of transfer regions of a Thiobacillus ferrooxidans plasmid: relatedness to plasmids RSF1010 and pSC101. Mol Microbiol 4, 1381-1391.

Eisenberg, D. (1984). Three-dimensional structure of membrane and surface proteins. Annu Rev Cell Biol 6, 247-296.

Frere, J., Novel, M. \& Novel, G. (1993). Identification of the thetatype minimal replicon of the Lactococcus lactis CNRZ270 lactose-protease plasmid pUCL22. Curr Microbiol 27, 97-102.

Frey, J., Bagdasarian, M. M. \& Bagdasarian, M. (1992). Replication and copy number control of the broad-host-range plasmid RSF1010. Gene 113, 101-106.

Gruss, A. \& Ehrlich, S. D. (1989). The family of highly interelated single stranded deoxyribonuleic acid plasmids. Microbiol Rev 53, 231-241.

Heuermann, D. \& Haas, R. (1995). Genetic organization of a small cryptic plasmid of Helicobacter pylori. Gene 165, 17-24.

Higgins, D. G. (1994). CLUSTAL v : multiple alignment of DNA and protein sequences. Methods Mol Biol 25, 307-318.

Kanatani, K., Tahara, T., Oshimura, M., Sano, K. \& Umezawa, C. (1995). Identification of the replication region of Lactobacillus acidophilus plasmid pLA103. FEMS Microbiol Lett 133, 127-130.

Kiewiet, R., Bron, S., de Jonge, K., Venema, G. \& Seegers, J. F. M. L. (1993). Theta replication of the lactococcal plasmid pWV02. Mol Microbiol 10, 319-327.

Lee, J., Ametani, A., Enomoto, A., Sato, Y., Motoshima, H., Ike, F. \& Kaminogawa, S. (1993). Screening for the immunopotentiating activity of food microorganisms and enhancement of the immune response by Bifidobacterium adolescentis M101-4. Biosci Biotechnol Biochem 57, 2127-2132.

Leenhouts, K. J., Toiner, B., Bron, S., Kok, J., Venema, G. \& Seegers, J. F. M. L. (1991). Nucleotide sequence and characterization of the broad host range lactococcal plasmid $\mathrm{pWV} 01$. Plasmid 26, 55-66.

Loosmore, S. M., Yang, Y. P., Coleman, D. C., Shortreed, J. M., England, D. M., Harkness, R. E., Pele, S. C. \& Klein, M. H. (1996). Cloning and expression of the Haemophilus influenzae transferrin receptor genes. Mol Microbiol 19, 575-586.

Matteuzzi, D., Brigidi, P., Rossi, M. \& DiGioia, D. (1990). 
Characterization and molecular cloning of Bifidobacterium longum cryptic plasmid pMB1. Lett Appl Microbiol 11, 220-223.

Missich, R., Sgorbati, B. \& LeBlanc, D. J. (1994). Transformation of Bifidobacterium longum with pRM2, a constructed Escherichia coli-B. longum shuttle vector. Plasmid 32, 208-211.

Park, M. S., Lee, K. H. \& Ji, G. E. (1997). Isolation and characterization of two plasmids from Bifidobacterium longum. Lett Appl Microbiol 25, 5-7.

Park, S., Wong, S., Wong, L. \& Doi, R. (1989). Bacillus subtilis gene $(a p r E)$ is expressed from a $\sigma \mathrm{A}(\sigma 43)$ promoter in vitro and in vivo. $J$ Bacteriol 171, 2657-2665.

Prasad, R., De Wergifosse, P., Goffeau, A. \& Baizi, E. (1995). Molecular cloning and characterization of a novel gene of Candida albicans, CDR1, conferring multiple resistance to drugs and antifungals. Curr Genet 27, 320-329.

Rossi, M., Bridigi, P., Gonzalez Vara y Rodriguez, A. \& Matteuzzi, D. (1996). Characterization of the plasmid pMB1 from Bifidobacterium longum and its use for shuttle vector construction. Res Microbiol 147, 133-143.
Sambrook, J., Fritsch, E. F. \& Maniatis, T. (1989). Molecular Cloning: a Laboratory Manual, 2nd edn. Cold Spring Harbor, NY: Cold Spring Harbor Laboratory.

Seegers, J. F. M. L., Bron, S., Franke, C. M., Venema, G. \& Kiewiet, R. (1994). The majority of lactococcal plasmids carry a highly related replicon. Microbiology 140, 1291-1300.

Sgorbati, B., Scardovi, V. \& LeBlanc, D. J. (1986). Related structures in the plasmid profiles of Bifidobacterium asteroides, $B$. indicum and B. globosum. Microbiologica 9, 443-456.

Tatyana, V. I. \& Eugene, V. K. (1992). Conserved sequence motifs in the initiator proteins for rolling circle DNA replication encoded by diverse replicons from eubacteria, eucaryotes and archaebacteria. Nucleic Acids Res 20, 3279-3285.

Wang, A. \& Macrina, L. (1995). Streptococcal plasmid pIP501 has a functional oriT site. J Bacteriol 177, 4199-4206.

Received 19 May 1998; revised 6 November 1998; accepted 11 November 1998. 